Journal of Southeast Asian

\title{
Book Review: Facing the Khmer Rouge: A Cambodian Journey, by Ronnie Yimsut
}

Molly Trinh Wiebe

The University of Texas at Austin, mwiebe@utexas.edu

\section{Recommended Citation}

Wiebe, Molly Trinh (2013) "Book Review: Facing the Khmer Rouge: A Cambodian Journey, by Ronnie Yimsut," Journal of Southeast Asian American Education and Advancement. Vol. 8 : Iss. 1, Article 11. DOI: 10.7771/2153-8999.1066

Available at: https://docs.lib.purdue.edu/jsaaea/vol8/iss1/11

This document has been made available through Purdue e-Pubs, a service of the Purdue University Libraries. Please contact epubs@purdue.edu for additional information.

This is an Open Access journal. This means that it uses a funding model that does not charge readers or their institutions for access. Readers may freely read, download, copy, distribute, print, search, or link to the full texts of articles. This journal is covered under the CC BY-NC-ND license. 


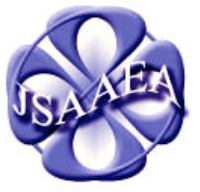

Volume 8 (2013)
Journal of Southeast Asian American Education \& Advancement

WWW.JSAAEA.org
A peer-reviewed scholarly journal published by the National Association for the Education \& Advancement of Cambodian, Laotian, and Vietnamese Americans (NAFEA)

\title{
Yimsut, R. (2011). Facing the Khmer Rouge: A Cambodian Journey. New Brunswick, NJ: Rutgers University Press. 239 pp. \$26.95 (paperback). ISBN: 9780813551524.
}

\author{
Reviewed by \\ Molly Trinh Wiebe \\ The University of Texas at Austin
}

Facing the Khmer Rouge: A Cambodian Journey is a poetic memoir about Ranachith "Ronnie" Yimsut's escape from the atrocities of the Khmer Rouge in Cambodia, his journey through the refugee camps in Thailand, and his immigration to the United States. Facing the Khmer Rouge is an honest and reflexive memoir about one of the world's greatest evils inflicted on humanity. Yimsut artfully unveils the realities of war and the physical and psychological violence infringed on human individuals. At the same time, this memoir makes transparent the complexities of displaced refugee survivors and a struggle that involves negotiating and navigating identities and spaces in a foreign world. Thus, the memoir is an effort to find personal healing and peace, and most importantly, it is a critical call for justice and social action for a country worth loving and fighting for.

In revisiting my old recorded memories and writing this book, I ripped open old wounds that never really healed. It was terrible, so horrible of a torture to write out my memories. What kept me going was knowing that I had to express memories or die. Soon after I wrote the first paragraph, the dam broke. I cried, reliving memories of good and bad times. For days, I couldn't sleep. I cried myself to sleep and woke up shivering, in tears. The anguish and pain were as real as the day they happened. Even as I write these words, the long-ago event feels like yesterday. (p. xvi)

Facing the Khmer Rouge begins in Cambodia before the war as Yimsut recalls growing up in Siem Reap surrounded by nature. He was born into a loving family that extended beyond his father, mother, sisters, brothers to include a close-knit community. He loved them fiercely and drew courage and comfort from each of them. Yimsut describes a childhood that was blissful and adventurous until the age of nine when Pol Pot and his regime, the Khmer Rouge took power. As a young boy, Yimsut experienced firsthand the struggle and change in Cambodia's

\section{@)}

SOBRERIGHISRESERVED Readers are free to copy, display, and distribute this article, as long as the work is attributed to the author(s) and the Journal of Southeast Asian American Education \& Advancement, it is distributed for noncommercial purposes only, and no alteration or transformation is made in the work. More details of this Creative Commons license are available at http://creativecommons.org/licenses/by-nc-nd/3.0/. All other uses must be approved by the author(s) or JSAAEA. 
political regime. He saw the confusion and fear spread among the Cambodian citizens and the violence endured by his family and community. Life moved from bliss to muddy trenches and escaping B52 bombs and whirring bullets became the routine.

These are some of my happiest memories as a little boy in Cambodia. My family loved one another dearly, I had my neighbors and my community to rely upon, and most importantly, I had a country to call my own.

Before I lost my childhood, I lost them all. (p. 15)

The memoir moves into a revealing profile of the Khmer Rouge - their power, control tactics, and the terror exerted on the people of Cambodia. Angkar, elites within the Khmer Rouge, forced Cambodian citizens - including Yimsut and his family-into labor camps located in the countryside. Within these camps there was constant and pervasive surveillance, torture and genocide.

Life was strictly controlled. Eating, sleeping, work, dating, marriage, and even the bearing of children were regulated. Angkar completely controlled us now. Freedom of expression and movement disappeared. Angkar dictated what we did, what kind of clothes we wore, whom we would marry. There was not private property, thought, or opinion - not in the open, anyway. (p. 64-66)

Under the Khmer Rouge regime, death was always a near step away. At the massacre on $T a$ Source Hill, Yimsut was beaten unconscious and left for dead. When he regained consciousness he realized that bodies were piled on top of him-bodies of his family and friends. He escapes. In the mist of his escape, Yimsut finds himself joining a resistance group. It is with them that he gained a chance to fight back and seek vengeance for his family whose lives were brutally murdered. The resistance, however, lacked the resources to prove effective against the Khmer Rouge and was short lived. As the Khmer Rouge gains more power and issues more restraints on the Cambodian citizens, Yimsut makes the decision to seek refuge in Thailand. With good omen and fortune, Yimsut finally reach the borders of Thailand.

... it was 10:22 in the morning of February 2, 1978. It was a moment I'd never forget. The feeling of that moment can never be described by words. I, at sixteen years old, an orphan, had finally made it to freedom. At long last, we were free. Being in Thailand, even illegally, gave a sense of closure to my journey. (p. 123)

Upon arrival, Yimsut was sent to Buri Ram Prison, a Thai prison, where he endured more abuse from the inmates. He was later transported to Aranya Prathet Refugee Camp located on the Thai-Cambodian border where he met Brian T. Ellis with CBS News. This chance meeting gave Yimsut the opportunity to talk about tragedies suffered by the millions of Cambodians under the brutal Khmer Rouge regime. This initial documentation created more opportunities for him to speak about his experiences as a survivor and as a refugee in Thailand. Yimsut ultimately became the face for Cambodians who were victims of a genocidal regime. 
He caught me off-guard. I had left the horrors back in Cambodia, and I'd almost forgotten that my parents were dead. As I answered their questions I completely broke down. I couldn't help it. I bawled my heart out and they had to stop the camera. After a few minutes I calmed down. I didn't like crying in public. I was sixteen. I was tough.... My private pain wasn't private anymore. (p. 133-134)

Yimsut was eventually sponsored by his cousin and her family and ultimately immigrated to the United States. In the United States, Yimsut faced many challenges and stress as a displaced immigrant living in a host country. Yimsut writes openly about the bullying he encountered in school, his feelings of "separateness" as an adopted individual, and the pressures of acquiring the English language and assimilating into the American culture. With the support of his extended family, friends, and teachers, Yimsut overcame these challenges and graduated from the University of Oregon with a degree in landscape architecture.

I didn't think of Cambodia. I didn't want a car. I didn't want to drive. I wanted to be just like that white kid over there. I wanted to speak English with no accent. I just wanted to be accepted. (p. 148)

The memoir closes where it began with Yimsut returning to Cambodia. It was a journey necessary for him to find personal healing and inner peace. In Cambodia, he visited relatives and old friends who opened their doors to him during his escape. This initial journey inspired Yimsut to return and dedicate time and effort toward rebuilding Cambodia. On his third visit to Cambodia, Yimsut summoned the courage to walk the narrow path down to Ta Source Hill, where his family and friends perished, and where he was left to die.

I felt the helplessness once more. The screams and groans returned, but I knew only I could hear them.... My consciousness slipped in and out, between past and present. I clamped down on my terror and walked ahead...toward the spot where I was left to die. I felt fear, bitter pain, and sharp anger. The grief brought me to my knees. I wept. A feeling of relief came over me. I had returned at long last. (p. 202)

In writing this memoir, Yimsut poignantly captures an important piece of Cambodian history by providing an insider's perspective into the atrocities endured by many Cambodian citizens during the reign of the Khmer Rouge. By tracing his personal lived-experiences, Yimsut's memoir offers more than a story about a survivor's triumph. His memoir provides insight into the realities faced by many survivors as they assume the social identity as an immigrant and their hardships of confronting social displacement, immigration, and the terrains of a host country. Furthermore, he makes available the experiences of how immigrants navigate and negotiate between the complexities of hybrid identities and social worlds and the pressures of cultural assimilation. I believe this book will serve well for those interested in learning about the history of Cambodia, the Khmer Rouge, and immigrant experiences. 


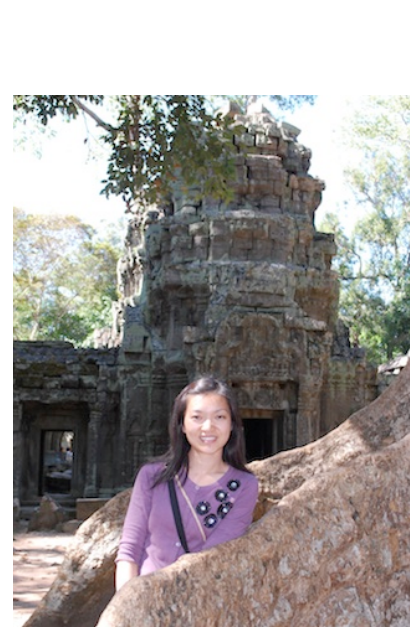

\section{About the Author}

Molly Trinh Wiebe is a doctoral student in Curriculum and Instruction with a program focus in Language and Literacy studies at The University of Texas at Austin. Her research interests include teacher education, out-of-school literacy, identity, and social justice education. She has taught elementary and middle school, and English as a Second Language $\left(\mathrm{K}-8^{\text {th }}\right)$ in California. 


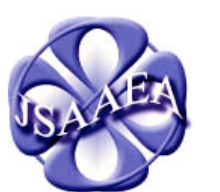

Volume 8 (2013)

\section{Journal of Southeast Asian American Education \& Advancement}

\author{
WwW.JSAAEA.org
}

\section{Editor}

Dr. Wayne E. Wright

University of Texas, San Antonio

\author{
Associate Editors \\ Dr. Chhany Sak-Humphry \\ University of Hawaii at Manoa
}

Dr. Phitsamay Sychitkokhong Uy

University of Massachusetts, Lowell

\section{Book Review Editor}

Dr. Vichet Chhuon

University of Minnesota

\section{Creative Works Editor \\ Bryan Thao Worra \\ Lao Assistance Center}

Special Advisor

Gregory Green

Curator, Echols Collection on Southeast Asia, Cornell University Library

\author{
Journal Manager \\ Sovicheth Boun \\ University of Texas, San Antonio
}

A peer-reviewed scholarly journal published by the

National Association for the Education \& Advancement of Cambodian, Laotian, and Vietnamese Americans (NAFEA)

Comments and questions for the editorial staff may be directed to jsaaea@lists.sis.utsa.edu

\section{Editorial Review Board}

\author{
Dr. Steve Arounsack \\ California State University, Stanislaus \\ Dr. Phala Chea \\ Lowell Public Schools \\ Dr. Loan Dao \\ University of Massachusetts, Boston \\ Dr. Changming Duan \\ University of Missouri, Kansas City \\ Dr. Jeremy Hein \\ University of Wisconsin - Eau Claire \\ Dr. Samlong Inthaly \\ Minneapolis Public Schools \\ Dr. Kevin K. Kumashiro \\ University of Illinois, Chicago
}

\author{
Dr. Carl L. Bankston III \\ Tulane University \\ Dr. George Chigas \\ University of Massachusetts, Lowell \\ Dr. Hien Duc Do \\ San Jose State University \\ Dr. Sophal Ear \\ U.S. Naval Postgraduate School \\ Dr. Nancy H. Hornberger \\ University of Pennsylvania \\ Dr. Peter Nien-Chu Kiang \\ University of Massachusetts, Boston \\ Dr. Ha Lam \\ Arizona State University
}



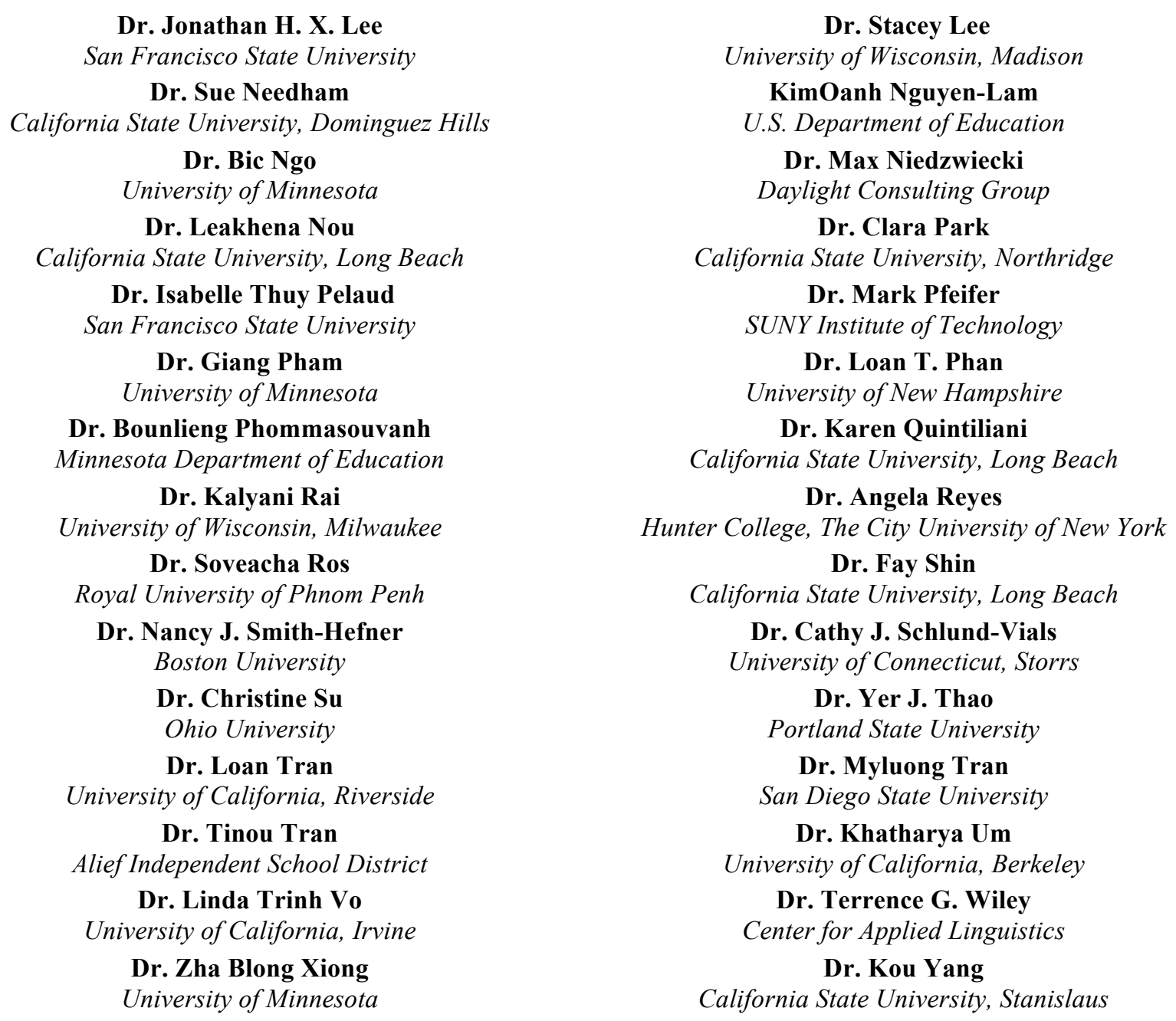

\section{Doctoral Student Editorial Review Board}

\author{
Keo Chea-Young \\ University of Pennsylvania \\ Ketmani Kouanchao \\ California State University, Fullerton \\ Ravy Lao \\ University of California, Santa Barbara \\ Thien-Huong Ninh \\ University of Southern California \\ Vanna Som \\ Harvard University \\ Krissyvan Truong \\ Claremount Graduate University \\ Yang Sao Xiong \\ University of California, Los Angeles
}

\author{
Annie BichLoan Duong \\ San Joaquin County Office of Education \\ Peter Tan Keo \\ Columbia University \\ Monirith Ly \\ Texas State University-San Marcos \\ Malaphone Phommasa \\ University of California, Santa Barbara \\ Alisia Tran \\ University of Minnesota \\ Silvy Un \\ University of Minnesota \\ Yeng Yang \\ University of Texas, San Antonio
}

